\title{
Ion Torrent sequencing and pipeline assembly of the first genome sequence of a mesophilic syntrophic acetate oxidizing bacterium [SAOB]
}

\author{
Shahid Manzoor', Erik Bongcam-Rudloff', Anna Schnürer², Bettina Müller ${ }^{2} \bowtie$ \\ 'Department of Animal Breeding and Genetics Science, Swedish University of Agricultural Science, SLU Global \\ Bioinformatics Centre, Uppsala, Sweden \\ 2Department of Microbiology, Swedish University of Agricultural Sciences, Uppsala BioCenter, Uppsala, Sweden
}

\section{Motivation and Objectives}

Syntrophic acetate oxidising bacteria (SAOB) have been identified as key organisms for efficient biogas production from protein rich materials under moderate conditions. Tepidanaerobacter acetatoxydans strain Rel is the first reported mesophilic SAOB which genome has been sequenced (Manzoor et al., 2013). Growth experiments and genetic studies allocated $T$. acetatoxydans to the physiological group of homoacetogens producing acetate through the Wood-Ljungdahl pathway when growing heterotrophically (Manzoor et al., 2013, Westernholm et al., 2011). However, when growing in syntrophy with methanogens, SAOB reverse this pathway and oxidise acetate to hydrogen and carbon dioxide (Müller et al., 2012, Hattori et al., 2005, schnürer et al., 1997).

\section{Motivation and Objectives}

Bioinformatics analysis might aid us to define general features being essential for maintaining a syntrophic lifestyle and to answer question concerning regulation, energy conservation and electron transfer mechanisms. This knowledge will enable us to further understand the mechanisms triggering $S A O$ in different environments, to monitor the activities of known SAOB and to find new isolation strategies.

\section{Methods}

The genome was sequenced by lon Torrent $\mathrm{PGM}^{\mathrm{TM}}$ Systems and we assembled the genome by using a comparative pipelined approach by using MIRA3 for mapping and Newbler 2.8 for de novo assembly. The finished genome was annotated with the annotation tools provided by MaGe (Microbial Genome Annotation \& Analysis Platform).

\section{Results and Discussion}

Our comparative approach with mapping and de novo assembly contributed successfully for finishing the bacterial genomes with high accuracy and less PCR work. After complete genome assembly and annotation (Table 1), a first genome analysis confirmed the two fhs clusters identified by Müller et al. (Müller et al., 2012) as well as the suggested operon structure including all genes encoding the Wood-Ljungdahl pathway with one exception: No format dehydrogenase has been identified underlying the observed inability of this organism to establish an autotrophic lifestyle (Müller et al., 2012). ATP seems to be generated by substrate level phosphorylation exclusively because no complete FOFI-ATP synthase has been found. Further two V-type ATPase operons, a cluster encoding an Rnf complex and several hydrogenases clusters have been identified and might contribute to the energy conserving systems of the cell.

Table 1. Genomic features of SAOB Genome.

\begin{tabular}{ccccccccc}
\hline Strain & $\begin{array}{c}\text { T. size } \\
\text { (bp) }\end{array}$ & $\begin{array}{c}\text { T. Protein } \\
\text { coding } \\
\text { genes }\end{array}$ & $\begin{array}{c}\text { Avg. CDS } \\
\text { Lgth. }\end{array}$ & $\begin{array}{c}\text { Avg. } \\
\text { Interg. } \\
\text { Lgth. }\end{array}$ & $\begin{array}{c}\text { Total } \\
\text { rRNAs }\end{array}$ & $\begin{array}{c}\text { Total } \\
\text { tRNAs }\end{array}$ & $\begin{array}{c}\text { Protein } \\
\text { Coding } \\
\text { Density }\end{array}$ & $\begin{array}{c}\text { G+C } \\
\%\end{array}$ \\
\hline TepRe1 & $2,759,867$ & 2,524 & 917 & 136 & 6 & 52 & 86.92 & 38 \\
\hline
\end{tabular}




\section{References}

Hattori S, Galushko AS, Kamagata Y, Schink B. (2005) Operation of the CO dehydrogenase/acetyl coenzyme A pathway in both acetate oxidation and acetate formation by the syntrophically acetate-oxidizing bacterium Thermacetogenium phaeum. J. Bacteriol. 187: 3471-3476.

Manzoor S, Bongcam-Rudloff E, Schnürer A, Müller B. (2013) Tepidanaerobacter acetatoxydans strain Rel: The first genome sequence of a syntrophic acetate oxidizing bacteria. Genome Announc. 1: e00213-12.
Müller B, Sun L, Schnürer A. (2012) First insights into the syntrophic acetate oxidising bacteria (SAOB) - a genetic study. Microbiology Open (accepted).

Schnürer A, Svensson BH, Schink B. (1997). Enzyme activities in and energetics of acetate metabolism by the mesophilic syntrophically acetate-oxidizing anaerobe Clostridium ultunense. FEMS Microbiol letters 154: 331-336.

Westerholm M, Roos S, Schnürer A. (2011): Tepidanaero-bacter acetatoxydans sp. nov., an anae-robic, syntrophic acetateoxidizing bacterium isolated from two ammonium-enriched mesophilic methanogenic processes. Syst. Appl. Microbiol. 34: 260-266. 